\title{
Comment
}

\section{RECENT DEVELOPMENTS IN CALIFORNIA LABOR LAW*}

The decisions of the California Supreme Court in three recent cases, Garmon v. San Diego Bldg. Trades Council, ${ }^{1}$ Chavez v. Sargent, ${ }^{2}$ and Retail Clerks' Union v. Superior Court, ${ }^{3}$ mark the beginning of a new period of development in judicial control of peaceful picketing and economic pressure by labor unions. It is the purpose of this Comment to examine the status of the California law governing organizational and recognitional picketing, peacefully conducted, ${ }^{4}$ in the light of these decisions. The problein of federal pre-emption of the field of labor relations affecting interstate commerce, also at issue in Garmon, has been discussed elsewhere, ${ }^{5}$ and questions involving federal law will be considered only insofar as they affect the substantive content of California law.

The plaintiffs in the Garmon case, the earliest of the three, sought injunctive relief and damages against the San Diego Building Trades Council for peacefully picketing plaintiff's lumber company in support of demands that the company execute a union shop agreement covernig its employees, none of whoin were members of the union or desired to become members. ${ }^{6}$ Upon appeal the California Supreme Court affirmed the judgment of the trial court granting the relief requested, ${ }^{7}$ and after the decision had been vacated and remanded by the United States Supreme Court for clarification, the California Supreme Court reversed the injunction (as required under the federal decision because of pre-emption of the field by the federal government) but affirned the award of damages. ${ }^{8}$ Although the decision was subsequently reversed by the United States Supreme Court on the pre-emption issue, it must still be taken as the law of California. ${ }^{9}$

The significant feature of the second Garmon decision was its apparent conflict with a lime of cases going back to McKay v. Retail Auto. Salesmen's Union ${ }^{10}$ assert-

* The decision of the California Supreme Court in Petri Cleaners, Inc. v. Automotive Employees Local 88, L.A. Civil No. 25143, January 26, 1960, was released after this issue of the Review had gone to press and hence is not discussed. The decision indicates that the court has again reversed itself.

149 Cal. 2d 595, 320 P.2d 473 (1958), rev'd, 359 U.S. 236 (1959).

252 A.C. 174,339 P.2d 801 (1959).

352 A.C. 232,339 P.2d 839 (1959), cert. denied, 361 U.S. 864 (1959).

4 Under California law it is clear that injunctive relief and damages are available for picketing involving violent conduct, and where past picketing has been so "irrevocably blended" with acts of violence as to give any further picketing a menacing appearance, all picketing may be enjoined. Steiner v. Long Beach Local 128, Oil Workers Int'l Umion, 19 Cal. 2d 676, 123 P.2d 20 (1942).

546 CalfF. L. REv. 643 (1958). See Comment, State Jutrisdiction Over Torts Arising from Federally Cognizable Labor Disputes, 68 Y $\mathrm{YLE}$ L.J. 308 (1958). Recent statutory changes have broadly expanded State jurisdiction and probably the applicability of State law by restoring jurisdiction to the States of all lahor disputes in which the NLRB declines to exercise jurisdiction. Labor-Management Reporting and Disclosure Act of 1959, $\$ 701,73$ Stat. 519, 29 U.S.C.A. \$ 164(c) (Supp. 1959).

6 The substance of the findings of the trial court is set forth in greater detail in the vacated opinion of the District Court of Appeal printed at 273 P.2d 686 (1954). The picketing was found to he aimed primarily at customers rather than employees since the pickets followed company trucks leaving the lumber yard so as to discourage persons from making purchases there. The picket signs, however, seen to have been worded as thougl directed solely at the employees.

7 Garmon v. San Diego Bldg. Trades Council, 45 Cal.2d 657, 291 P.2d 1 (1955), vacated and remanded, 353 U.S. 26 (1957).

8 Garmon v. San Diego Bldg. Trades Council, 49 Cal. 2d 595, 320 P.2d 473 (1958), rev'd, 359 U.S. 236 (1959).

${ }^{9}$ See Chavez v. Sargent, 52 A.C. 174, 212, 339 P.2d 801, 826 (1959), where it is so treated.

1016 Cal. 2d 311, 106 P.2d 373 (1940), cert. denied, 313 U.S. 566 (1941). 
ing that peaceful picketing in support of demands for a union or a closed shop is not unlawful even though none of the employees are nembers of the union. Garmon II purported not to overrule these earlier precedents and treated them ratler as having been "superseded," leaving the task of dealing with the precedents and defining the scope of the law stated in Garmon to subsequent decisions. It is this task to which the Chavez and Retail Clerks' Union cases were addressed.

\section{I}

\section{HISTORICAL BACKGROUND}

In order to understand the background of these decisions a review of the major events in the California law of union representation is essential. Two types of picketing by a union seeking to represent a group of employees are commonly distinguished: the term "recognitional picketing" is used to refer to picketing of the employer with the object of compelling the employer to recognize the union as the bargaining representative of all the employees, while the term "organizational picketing" is used to refer to picketing aimed at encouraging the employees to join the union by means of direct persuasion.

The first explicit recognition in the California law of a right to engage in organizational and recognitional economic pressure activities (specifically, to seek a closed slop by means of a boycott) appears to have been in J.F. Parkinson Co. v. Building Trades Council.11 Although a majority of the court did not concur in any single opimion, the opinions written reflected a laissez-faire view, leaving opposing economic interests free to compete in any way not involving violence, fraud, or invasion of contract rights.

A siguificant statutory inodification occurred in 1933 when the legislature adopted the provisions of Cahifornia Labor Code sections $920-21,923^{12}$ as a compromise of an attempt to pass an anti-injunction statute modelled on the NorrisLaGuardia Act. ${ }^{13}$ The new provisions received a supreme court interpretation on the issue of organizational picketing in three cases decided together in 1940: $M c$ Kay v. Retail Auto. Salesmen's Union, ${ }^{14}$ Shafer v. Registered Pharmacists Union, ${ }^{15}$

$11154 \mathrm{Cal} .581,98 \mathrm{Pac} .1027$ (1908). It should be observed, however, that picketing was not regarded as a legitimate means in seeking a union or closed shop at that time. $C f$. Pierce v. Stablemen's Union, 156 Cal. 70, 103 Pac. 324 (1909).

12 CAL. LAB. CODE $\S 921$ reads in part as follows: "Every promise . . . between any employee or prospective employee and his employer . . . or any other person is contrary to public policy if either party thereto promises ... (a) To join .... a labor organization or .... an enzployer organization, (b) Not to join ... a labor organization or ... an employer organization, (c) To withdraw from an employment relation in the event that he joins ... a labor organization or ... an employer organization. Such promise shall not afiord any basis for the granting of legal or equitable relief ... against a party to such promise ...."

CAL. LAB. CODE $§ 923$ reads in part as follows: "[T]he public policy of this State is declared as follows: Negotiation of terms and conditions of labor should result from voluntary agreement between employer and employees .... [T] he indiviclual unorganized worker is lielpless to exercise actual liberty of contract and to protect his freedom of labor .... Therefore it is necessary that the individual workman have full freedom of association, self-organization, and designation of representatives of his own choosing, to negotiate the terms and conditions of his employment, and that he shall be free from the interference, restraint, or coercion of employers . . . in the designation of such representatives or in self-organization or in other concerted activities for the purpose of collective bargaining or other nutual aid or protection."

1347 Stat. 70 (1932), 29 U.S.C. $\$ \$ 101-15$ (1958). The origin of the California legislation is discussed briefly in Shafer v. Registered Pharmacists Union, 16 Cal.2d 379, 385, 106 P.2d 403,407 (1940), and in note 17 infra.

1416 Cal. 2d 311, 106 P.2d 373 (1940).

1516 Cal. 2d 379, 106 P.2d 403 (1940). 
and C. S. Smith Metropolitan Market Co. v. Lyons. ${ }^{16}$ The court construed the provisions, in the hight of the declared legislative intention to foster labor unions, as being intended only to prohibit contracts in which the employee promised not to join a union, as distinguished from union or closed shop contracts. ${ }^{17}$ Although McKay and Shafer involved partially umonized employers, Metropolitan Market, whose facts were essentially identical to those later to arise in Garmon, did not. ${ }^{18}$ Hence, Metropolitan Market gave specific approval to minority picketing. The court rationalized its support of minority picketing by finding a specific union interest in conditions in the unorganized portions of the industry affected, on the basis of their competitive effect on the organized shops. ${ }^{10}$

1016 Cal. 2d 389, 106 P.2d 414 (1940).

17 Shafer v. Registered Pharmacists Union, 16 Cal.2d 379, 387, 106 P.2d 403, 407 (1940). It would seem at least doubtful that the legislature would have used such explicit language as "to join ... a labor organization or ... not to join . . . a labor organization ..." in Labor Code $\S 921$, if it had been intended that only the latter type of contract should be made unlawful, especially when the measure was a compromise one. The dissent in McKay v. Retail Auto. Salesmen's Union, 16 Cal.2d 311, 335, 106 P.2d 373, 386 (1940), presents the minority interpretation forcefully, along with some supporting legislative and judicial history.

The legislation originated in a "model act" drafted for the AFL and introduced in the legislatures of Ohio and Indiana in 1925 and subsequently proposed in many other States. See Witte, "Yellow Dog" Contracts, 6 WIs. I. Rev. 21, 28-29 (1930-31); Note, 81 U. PA. L. REv. 68, 72 (1932). The model act apphied only to contracts forbidding union membership and was silent on the subject of contracts requiring it. See Cochrane, Attacking the "Yellow Dog" in Labor Contracts, 15 Axr. LAB. LEG. REv. 151 (1925), in wbich it is printed in full. The model act was introduced in the California Legislature in 1927 and subsequent years but failed of passage. In 1932 its provisions were imcorporated without substantial change into the Norris-LaGuardia Act passed by Congress. 47 Stat. 70, 29 U.S.C. $\$ 102-03$ (1958). A modified version of the NorrisLaGuardia Act was proposed to the California Legislature in 1933 as Assembly Bill 315 and passed after deletion of the anti-injunction provisions and after other amendments. It is this modified version wbich is the present law and which includes the disputed language on agreements to join a umion. Prior to $M c K a y$ the provision seems to have been regarded as banning the union and elosed shops (see, e.g., Fraenkel, Recent Statutes Affecting Labor Injunctions and Yellow Dog Contracts, 30 Irr. L. REv. 854, 859 n.29 (1936)), and in 1939 an unsuccessful attempt was made to pass legislation specifically authorizing the closed and umion shops. The bill, Assembly Bill 373 , passed the assembly but not the senate.

The court gave two reasons for holding the provision inapplicable to union and closed shop agreements: (1) The prohibition extended only to agreements between employer and employee, not those between union and employer (though this would seem merely to make the agreement between union and employer one requiring the employer to perform an unlawful act), and (2) the term "labor organization" apphes only to company unions in the clause covering agreements to join a union and to bona fide unions in the clause covering agreements not to join a union. Shafer v. Registered Pharmacists Union, 16 Cal.2d 379, 386-87, 106 P.2d 403, 407-08 (1940).

18 The court chose to give its interpretation of Labor Code \$\$ 920-21, 923 in Shafer, in which all but one of the employees affected were actually on strike, and to rely on that interpretation in the McKay and Metropolitan Market cases. The McKay case was essentially a jurisdictional dispute between a local employee association and a group of unions, in which the employees belonging to the association sought relief. In the Metropolitan Market case none of the employees were members of the union and injunctive relief against picketing by the union was sought by the employer.

19 C. S. Smith Metropohtan Market Co. v. Lyons, 16 Cal. 2d 389, 401, 106 P.2d 414, 421 (1940). A substantial number of cases since the decisions in McKay, Shafer, and Metropolitan Market have cited them for the proposition that a union has an interest in nonunion shops, even where the employees are bostile, sufficient to support union or closed shop demands. See Park \& Tilford Import Corp. v. International Bhd. of Teamsters, 27 Cal. 2d 599, 165 P.2d 891 (1946); James v. Marinship Corp., 25 Cal. 2d 721, 155 P.2d 329 (1944); Emde v. San Joaquin County Cent. Labor Council, 23 Cal.2d 146, 143 P.2d 20 (1943) ; Steiner v. Long Beach Local 128, Oil Workers Int'] Union, 19 Cal. 2d 676, 123 P.2d 20 (1942); Sontag Chain Stores Co. v. Superior Court, 18 Cal. 2d 92, 113 P.2d 689 (1941). 
A number of events occurring after the $M c K a y$ decision were to figure in the result in Garmon. One was the enactment of the Jurisdictional Strike Act ${ }^{20}$ by the California Legislature in 1947, making jurisdictional strikes unlawful. A second factor was the retreat of the United States Supreme Court from the policy of Thornhill v. Alabama ${ }^{21}$ and $A F L$ v. Sroing, ${ }^{22}$ which had held that peaceful picketing, mcluding organizational picketing, constituted the exercise of free speech protected against State action under the due process clause of the fourteenth amendment. This retreat culminated in International Bhd. of Teamsters v. Vogt, Inc., ${ }^{23}$ holding a State free to enjoin peaceful organizational picketing if in violation of a definite State policy other than a general policy against all picketing. A third factor was the change of the federal law with the adoption of the LaborManagement Relations Act ${ }^{24}$ in 1947, subjecting recognitional picketing by minority unions to more stringent control. ${ }^{25} \mathrm{~A}$ fourth factor was the development of the "unlawful purpose" doctrine to cover a growing body of California law prohibiting picketing aimed at an unlawful purpose and imposing restrictions or refinements on the Metropolitan Market rule as applied to particular circumstances, thus subordinating the declared union imterest in conditions im nonumion shops to other stronger policies.

One of the earliest of these latter cases involved racial discrimination in unions with closed shop contracts and enjoined observance of the contract as to the employees discriminated agaimst, the theory being that a closed shop and an arbitrarily closed union were not compatible. ${ }^{28}$ Similar reasoning prevailed where the discrimination was on other than racial grounds, as where picketing or economic pressure for a union sliop was exerted on a self-employed person who was excluded from membership in the union or allowed only inferior rights as a member. ${ }^{27}$ Other cases lave lield untruthful picketing, ${ }^{28}$ picketing pursuant to agreements in restraint of trade under the Cartwright Act, ${ }^{29}$ picketing in support of representation

20 CAC. LAB. CoDE $\S \S 1115-22$. For a study of the Jurisdictional Strike Act, see Aaron, The California Jurisdictional Strike Act, 27 So. CAL. L. REv. 237 (1954).

21310 U.S. 88 (1940).

22312 U.S. 321 (1941).

23354 U.S. 284 (1957).

2461 Stat. 136 (1947), 29 U.S.C. $\$ \$ 141-88$ (1958).

25 See, e.g., 61 Stat. 141 (1947), 29 U.S.C. $\$ 158(\mathrm{~b})(2)$ (1952).

26 James v. Marinship Corp., 25 Cal.2d 721, 155 P.2d 329 (1944). Accord, Williams v. International Bhd. of Boilermakers, 27 Cal. 2d 586, 165 P.2d 903 (1946); Thompson v. Moore Drydock Co., 27 Cal. 2d 595, 165 P.2d 901 (1946). The rule vas extended to cover picketing in support of racially discriminatory practices (proportional hiring) in Hughes v. Superior Court, 32 Cal. 2 d 850, 198 P.2d 885 (1948), aff'd, 339 U.S. 460 (1950).

27 Bautista v. Jones, 25 Cal. 2d 746, 155 P.2d 343 (1944); Riviello v. Journeyman Barbers Union, 88 Cal. App. 2d 499, 199 P.2d 400 (1948). In Thorman v. International Alliance of Theatrical Employees, $49 \mathrm{Cal} .2 \mathrm{~d} 629,320$ P.2d 494 (1958), where the applicant was qualified for membership in a union with a closed shop contract, except for failure to receive a favorable vote by the members, nuandamus was granted to require his admission.

28 Magill Bros. v. Building Serv. Employees' Int'I Union, 20 Cal.2d 506, 127 P.2d 542 (1942). Only the untruthful statements were enjoined.

29 CAL. Bus. \& Pror. Code \$\$ 16700-58. The recent cases include Alfred M. Lewis, Inc. v. Warehousemen \& Helpers Union, 163 Cal. App. 2d 771, 330 P.2d 53 (1958), where picketing was enjomed and damages were awarded for an attempt to drive an employer out of business pursuant to an agreement with competing employers; Alpha Beta Food Markets, Inc. v. Amalgamated Meat Cutters Workmen, 147 Cal. App. 2d 343, 305 P.2d 163 (1956), where a clause of a collective bargaining agreement requiring all fresh meats to be cut and packaged by members of the union was held void; and Kold Kist, Inc. v. Amalgamated Meat Cutters Local 421, 99 Cal. App. 2d 191, 221 P.2d 724 (1950), involving an agreement similar to that in the Alpha 
demands with respect to State or municipal employees, ${ }^{30}$ picketing to prevent a common carrier from fulfilling its obligation to render service to a business at which a labor dispute existed, ${ }^{31}$ and jurisdictional picketing ${ }^{32}$ to be unlawful. ${ }^{33}$ Thus, although the $M c K a y$ rule was accepted, the situations in which it was applicable were cut down. It was against this background that the California Supreme Court acted in Garmon.

\section{II \\ THE GARMON OPINIONS}

The first Garmon opinion ${ }^{34}$ construed the federal statute and found the picketing to be for an unlawful objective under the federal law and for that reason unlawful under California law. The idea seems to have been that it was the policy of the California law under the "unlawful purpose" doctrine to withhold privileged status from picketing for objectives which were not lawful under the federal law and that the California law therefore changed with the change in the federal law in $1947 .^{35}$ The United States Supreme Court in its consideration of the case found the opinion sufficiently obscure that it remanded to find out if State or federal law was beimg applied. ${ }^{36}$

The second Garmon opinion, ${ }^{37}$ decided, as were Garmon $I$ and $M c K a y$, by a 4-3 vote, placed the decision strictly on a State law basis and abandoned any rehance on federal law. ${ }^{38}$ After stating that, if the conduct complained of is unlaw-

Beta Food Markets case. The basic precedent in the field, Overland Publishing Co. v. H. S. Crocker Co., 193 Cal. 109, 222 Pac. 812 (1924), had previously been narrowly confined by a dictum in McKay v. Retail Auto. Salesmen's Union, 16 Cal.2d 311, 327, 106 P.2d 373, 382 (1940).

30 The cases include California v. Brotherhood of R.R. Trainmen, 37 Cal. 2d 412, 232 P.2d 857 (1951), cert. denied, 342 U.S. 876 (1951), holding that Labor Code $\$ 923$ does not apply to public employees and that while public agencies should negotiate with union representatives as to grievances and conditions of labor they may not accede to recognitional demands or accord collective bargaining privileges (decision reversed on other grounds in related proceedings in California v. Taylor, 353 U.S. 553 (1957)), and City of Los Angeles v. Los Angeles Bldg. Trades Council, 94 Cal. App.2d 36, 210 P.2d 305 (1949), where recognitional picketing of city construction projects was enjoined.

31 Northwestern Pac. R.R. v. Lumber Workers' Union, 31 Cal. 2d 441, 189 P.2d 277 (1948).

32 In re Kelleher, 40 Cal.2d 424, 254 P.2d 572 (1953); Sommer v. Metal Trades Council, 40 Cal. 2d 392, 254 P.2d 559 (1953); Voeltz v. Bakery Workers Union, 40 Cal. 2d 382, 254 P.2d 553 (1953); Seven Up Bottling Co. v. Grocery Drivers Union, 40 Cal.2d 368, 254 P.2d 544 (1953); Globe Dairy Lunch Co. v. Joint Executive Bd. of Culinary Workers, 117 Cal. App. 2d 190, 255 P.2d 94 (1953).

33 For further discussion of cases in which picketing has been held unlawful because aimed at an objective found to be unlawful, see generally, Tobriner, The Organizational Picket Line: Lawful Economic Pressure, 3 STAN. L. REv. 423 (1951).

34 Written by Justice Edinonds, author of the McKay, Shafer, and Metropolitan Market decisions.

35 Garmon v. San Diego Bldg. Trades Council, 45 Cal. 2d 657, 666, 291 P.2d 1, 7 (1955), relying on Park \& Tilford Import Corp. v. International Blid. of Teamsters, 27 Cal. 2d 599, 165 P.2d 891 (1946), and Lillefioren v. Superior Court, 31 Cal. 2d 439, 189 P.2d 265 (1948), cert. dismissed per curiam for want of juris., 335 U.S. 906 (1949).

30 San Diego Bldg. Trades Council v. Garnion, 353 U.S. 26 (1957).

37 Written by Justice Shenk. The dissent was written by Justice Traynor.

38 The dissent attacked the doctrine of incorporation of federal law in State law and distinguished the Park \& Tilford case on the basis that the changed federal law had been held to create no rights other than those defined and vindicated by NLRB action. Garmon v. San Diego Bldg. Trades Council, 49 Cal.2d 595, 624, 320 P.2d 473, 491 (1956) (dissent). While this is persuasive, it would seem that California shonld not be bound by federal procedural requirements in determining what to incorporate into its law. 
ful, it is tortious and gives rise to an action for damages (relying on the "unlawful purpose" cases), the court found the picketing unlawful under California Labor Code section $923 .^{39}$ Three factors were cited as reasons for departing from the interpretation of the statute announced in the McK.ay, Shafer, and Metropolitan Market cases: (1) Enactment of the Jurisdictional Strike Act, ${ }^{40}$ (2) the construction of substantially identical statutes adopted by other State courts, and (3) the elimination of the free speech argument by the United States Supreme Court decision in Vogt.41

The court appeared to acknowledge that the terms of the Jurisdictional Strike Act did not specifically cover the Garmon situation, but treated them as manifesting an intent that Cahifornia Labor Code section 923 should be construed in connection with them to change the rule adopted in $M c K a y{ }^{42}$ Moreover, the court pointed out that the Jurisdictional Strike Act nullified the rule of $M c K a y$ on its facts, and treated it as being impliedly overruled by Seven Up Bottling Co. v. Grocery Drivers Union, ${ }^{43}$ which held the Jurisdictional Strike Act constitutional.

The court also relied on decisions of other State courts construing statutes similar to California Labor Code section 923 under fact situations similar to Garmon and reaching the same result. ${ }^{44}$ While these cases may be persuasive, the dissent points out that similar interpretations lad been considered at the time of the $M c K a y$ decision and rejected. ${ }^{45}$

Closely related to the holdings of other State courts, and growing out of them, was the last factor cited, namely, the rejection by the United States Supreme Court of any constitutional protection for picketing in situations similar to Garmon.40 The elimination of the constitutional protection which had been provided for such

89 Set out in note 12 supra.

40 CAI. LAB. CODE §§ 1115-22.

41 International Bhd. of Teamsters v. Vogt, Inc., 354 U.S. 284 (1957).

42 "The foregoing provisions of the Labor Code, that is, sections 923 and 1115 through 1118 are in pari materia in that they relate to the sane general subject and should be considered together. They all represent an endeavor on the part of the Legislative to safeguard the rights of the individual workman and the employer in this important field of labor-management rerelationships." Garmon v. San Diego Bldg. Trades Council, 49 Cal. 2d 595, 608, 320 P.2d 473, 481 (1958). This construction of the expressed legislative intent in enacting the Jurisdictional Strike Act appears about as dubious as that used in reaching the result in the McKay case. The act originated in the Califormia Senate as Senate Bill 1493 (Reg. Sess. 1947). During the course of its consideration in the senate it was specifically amended to make organizational strikes unlawful, Cax. SENATE Jour. 2143 (Reg. Sess. 1947), and subsequently anended again to delete the provision, Cax. Senate Jour. 2254 (Reg. Sess. 1947). The senate amendment defined "organizational strike" as "concerted interference with an employer's ... business, the object of which is to require the employer ... to recognize ... a labor organization as the collective bargaining representative of any of his employees, wherever there are procedures . . . for . . . designation ... as . . . bargaining representatives . . . and such labor organization has not been so designated." Cax. Senate Jour. 2144 (Reg. Sess. 1947). The assembly also added a similar amendment and subsequently deleted it. The bill became law without such a provision.

4340 Cal. 2d 368, 254 P.2d 544 (1953).

44 The primcipal cases cited are Pappas v. Stacey, 151 Me. 36, 116 A.2d 497 (1955), appeal dismissed, 350 U.S. 870 (1955), and Vogt, Inc. v. International Bhd. of Teamsters, 270 Wis. 315, 74 N.W.2d 749 (1956), aff'd, 354 U.S. 284 (1957). An extensive list of similar State cases is available in Plant, Recognitional Picketing by Minority Unions in California, 9 SxaN. L. REv. 100, 120 n.84 (1956).

45 Garmon v. San Diego Bldg. Trades Council, 49 Cal. 2d 595, 623, 320 P.2d 473, 490 (1958) (dissent).

46 International Bhd. of Teamsters v. Vogt, Inc., 354 U.S. 284 (1957). 
picketing at the time of $M c K a y$ provided another ground on which to distinguish that case-although it seems preferable to regard the constitutional issue as only an alternative holding in $M c K a y$ rather than as the basis of the decision, as was suggested in Garmon II.

Two significant questions were left in uncertain status by the opinion in Garmon II. The first of these was whether organizational as well as recognitional picketing by minority unions had been found unlawful; the second, whether the decision would be extended beyond the minority union situation to make all union and closed shop denıands unlawful.

It had been suggested in an article written between the Garmon $I$ and Garmon II opinions that the case applied only to recognitional picketing. ${ }^{47}$ The theory was that California Labor Code section 923 seeks to free entployees fron interference by employers in choice of representatives, not outside eniployee groups where the interference is not formally exerted through the employer. Using this theory even Metropolitan Market could have been distinguished fron Garmon, since it may be interpreted as involving organizational rather than recognitional picketing.

Since the court was prepared to enjoin all picketing in Garmon (and indeed did so in Garmon I) and did not distinguish between organizational and recognitional activities, it would seem that the organizational picketing problen was impliedly resolved against its lawfulness. ${ }^{48}$ Only the court's failure to discuss Metropolitan Market, other than in the dissent, left the issue in uncertainty.

On the second question, whether union and closed shop deniands are unlawful in all cases or only when made by minority unions, Garmon $I I$ offered no substantial clue.

\section{III}

\section{THE CHAVEZ AND RETAII CLERKS' UNION OPINIONS}

The California Supreme Court decisions in Chavez v. Sargent 49 and Retail Clerks' Union v. Superior Court ${ }^{50}$ calne down over a year after Garmon II. Both arose out of injunction suits by employers seeking rehef under county ordinances prohibiting closed or union slop contracts, Chavez involving a union representing a majority of the employees affected and Retail Clerks' Union a union representing ouly a minority. The court found the county ordinances invahid on grounds they

47 Plant, Recognitional Picketing by Minority Unions in California, 9 Stan. L. Rev. 100, 118-29 (1956).

48 If only minority recognitional picketing were unlawful the appropriate remedy (absent the federal pre-emption problem in the case) would appear to have been to enjoin only the unlawful demands, not all picketing, but in Garmon $I$ the picketing itself was enjoined and in Garmon $I I$, although the judgment was reversed insofar as it awarded injunctive relief, this was done solely because of the pre-emption problem. Cf. Park \& Tilford Import Corp. v. International Bhd. of Teamsters, 27 Cal. 2d 599, 165 P.2d 891 (1946), where the court distinguished between picketing in support of an unlawful demand for a closed shop (under the then existing apphicable federal law) and picketing unaccompanied by such a demand on the employer and enjoined only the unlawful demands. The court treated the dispute as one between the union and the nonunion employees and held the union entitled to picket with the objective of gaining sufficient membership to be able eventually to make a lawful demand for a union shop under the federal law.

It should also be noted that the decisions in other States cited by Garmon II extended to organizational as well as recognitional picketing. See cases cited in note 44 supra.

4052 A.C. 174,339 P.2d 801 (1959).

8052 A.C. 232,339 P.2d 839 (1959). 
conflicted with the legislatively declared general labor policy of the State and held injunctive relief available under the State law in Retail Clerks' Union, but not in Chavez. The court's exposition of the law is given in the Chavez opinion. ${ }^{51}$

The court reaffirms its reliance on the unlawful purpose doctrine, ${ }^{52}$ the United States Supreme Court decision in the Vogt case, ${ }^{53}$ and California Labor Code section 923 as affected by the Jurisdictional Strike Act. ${ }^{54}$ But it is primarily in its exposition of the effect of the Jurisdictional Strike Act on the pre-existing law (both statutory and decisional) and in the development of a "majority rule" test for determining the validity of union and closed shop dernands that the court throws additional light on Garmon II. The court holds that for purposes of the Jurisdictional Strike Act "any group of einployees, organized or unorganized in the formal, conventional sense ... free of the proscribed employer influence... who determined and informed their employer through their authorized spokesman that they were unwilling to accede to the dennands of an organizer or unwanted union, and that they ... wished to continue in the established employer-employee relationship, ... . thereby act as and constitute a 'labor organization' within the meaning of sections 1117 and $1118 . " 55$ The court thus seeks to bring picketing by

51 The decision in Chavez was unanimous, with Justice Schauer writing the majority opinion, Justice McComb concurring specially as well as in the opinion of the court, and Justice Traynor and Chief Justice Gibson concurring only in the judgment. The decision in Retail Clerks Union was decided 4-2, with Justice Schauer writing the majority opinion, Justice Traynor the minority one and Justice $\mathrm{McComb}$ concurring as before.

52 Chavez v. Sargent, 52 A.C. 174, 209, 339 P.2d 801, 824 (1959).

53 Id. at 211,339 P.2d at 825 .

54 Id. at 212-17, 339 P.2d at 825-29.

55 Id. at 213-14, 339 P.2d at 826 . The dissent attacks this interpretation severely, referring to the creation of a fictitious labor organization" or an "unorganized organization" and arguing that a group whose purpose is to express a desire not to deal collectively with an employer cannot come within the terms of $\$ 1117$ (set out infra). Retail Clerks' Union v. Superior Court, 52 A.C. 232, 239, 242, 339 P.2d 839, 843, 845 (1959) (dissent). While it would seem possible to regard such a group as "dealing with an employer concerning grievances [or] labor disputes" within the terms of $\S 1117$, it seems difficult to suppose that the language used was intended to extend to unorganized employees. See note 42 supra.

The dissent also urges additional difficulties in applying the Jurisdictional Strike Act dircctly to the facts of Relail Clerks' Union. The burden of showing the existence of a labor organization is on the plaintiff under $\S 1117$, and no attempt was made to meet it, since the case was originally brought under a local ordinance prohibiting union or closed shop contracts rather than the Jurisdictional Strike Act. Moreover, it is difficult to see how the case can be said to have arisen out of a controversy between two labor organizations as to which had the exclusive right to bargain collectively or bave its members perform work for the employer, which appears to be required to come within the definition of jurisdictional strike in $\S 1118$ (set out infra). Id. at 243,339 P.2d at $845-46$ (1959) (dissent).

CAI. LAB. CODE $\S 1117$ reads in part as follows: "'Labor organization' means any organization or any agency or employee representation committee or any local unit thercof in which employees participate, and exists for the purpose, in whole or in part, or dealing with employers concerning grievances, labor disputes, wages, hours of employment or conditions of work ... not ... financed ... . or . . . interfered with . . . by the employer or any employer association within one year .... The plaintiff shall have the affinnative of the issue with respect to establishing the existence of a 'labor organization' as defined herein."

CAI. LAB. CODE § 1118 reads in part as follows: " ' $[\mathrm{J}]$ urisdictional strike' means a concerted refusal to perform work ... or any other concerted interference with an employer's ... business, arising out of a controversy between two or more labor organizations as to which of them has or should have the exelusive right to bargain collectively with an employer on behalf of his employees or any of them, or arising out of a controversy between two or more labor organizations as to which of them has or should have the exelusive right to have its members perforn work for an employer." 
a minority union directly within the Jurisdictional Strike Act, calling it "jurisdictional dispute pressure," and distinguishes such pressure froin what it regards as legitimate union security demands, in which the employees' authorized labor organization seeks a union shop or other union security agreement.

The court also continues to rely on California Labor Code section 923 as requiring the same result, noting that it makes no distinction between organized and unorganized workmen in proscribing employer interference with the freedom of the workman. ${ }^{56}$ It falls back on the Jurisdictional Strike Act, however, to justify its abandonment of the interpretation placed on that section in Metropolitan Market. .7

The "majority rule" test adopted to determine the lawfulness of union and closed shop demands and picketing in support of them energes in the court's reexamination of Labor Code sections 921 and 923 . The court reiterates the conclusion reached in Shafer that section 921 does not apply to the union and closed shop contract.58 The "full freedom" of the "individual workman" in designating "representatives of his own choosing" granted by section 923 is held to be limited by the countervailing advantage of united collective action which nust be balanced against it. ${ }^{59}$ Thus, the conclusion announced in 1940 in McKay, Shafer, and Metropolitan Market that the closed and union shops are lawful labor union objectives under California law is still valid, but the holding of those cases has been cut down

56 Chavez v. Sargent, 52 A.C. 174, 215, 339 P.2d 801, 827 (1959).

57 Id. at 194, 339 P.2d at 814. The court also in effect overrules Charles H. Benton, Inc. v. Painters Union, 45 Cal. 2d 677, 291 P.2d 13 (1955), which was decided at the same time as Garmon $I$ and followed the Metropolitan Market rule (without citing it), on the basis that the court did not then have occasion to consider the effect of the Jurisdictional Strike Act on the previous decisional law. Chavez v. Sargent, 52 A.C. 174, 218, 339 P.2d 801, 829 (1955).

The Hot Cargo and Secondary Boycott Act, CAL. LAB. CoDE $\$ \$ 1131-36$, adopted on referendum in 1942 and held unconstitutional in In re Blaney, 30 Cal. 2d 643, 184 P.2d 892 (1947), is mentioned as being indicative, along with the Jurisdictional Strike Act, of growing public concern over labor union activities. Chavez v. Sargent, 52 A.C. 174, 191, 339 P.2d 801, 812 (1959). Presumably the court seeks here to show a public mood indicating a need to re-examine the Metropolitan Market holding, rather than to revive the hot cargo legislation, although it is true that the constitutional basis of the Blaney decision has been greatly weakened snice the time that it came down.

58 Chavez v. Sargent, 52 A.C. $174,196,339$ P.2d 801, 815 (1959). Of the two grounds which were given in Shafer for finding Labor Code \$921 mapplicable the court rejects the one which interprets the term "labor organization" to mean company union on one line and bona fide union on the next, but adopts the other, which holds that the section invalidates only agreements between employer and employee, not between employer and umion. See note 17 supra.

50 Chavez v. Sargent, 52 A.C. 174, 198, 339 P.2d 801, 816 (1959). The dissent also severely criticizes this compromise interpretation of $\S 923$, asserting that if a minority union interferes with the freedom of the individual workman, so does a majority union, since in either case the nonunion employee is required to join the union against his wishes. While this is undoubtedly correct under a literal construction of the section, it is difficult to see how the dissent can find the union activity proper in both situations using the same type of construction of the statute. It is significant that it dces not refer to the terms of the statute in doing so. Retail Clerks' Union v. Superior Court, 52 A.C. 232, 241, 339 P.2d 839, 844 (1959) (dissent). It would seem that the result is frankly recognized by the majority as a compromise one reached on the basis of balancing opposing interests.

Nor is the dissent persuasive in suggesting that the nuajority opinion determines the relevant majority with "myopic vision" in looking only to the workmen directly affected, rather than looking to all workmen is competitive businesses and relying on public opinion and individual participation in union affairs to protect imdividual or local interests in the presence of a presumed majority acceptance. Such a course would seen to ignore two of the most significant factors in making a choice for or against the union-the conduct of the affairs of the local union concerned and the conduct of the employers involved. 
to require that the union represent a majority of the affected employees before it seeks such an arrangement. ${ }^{.0}$

The organizational picketing issue again was not separately discussed, perhaps because the form of injunction issued in Retail Clerks' Union and upheld by the court did not raise the question. ${ }^{61}$ The court does, however, make it clear that on its facts it regards Metropolitan Market, like $M c K a y$, as no longer the law, ${ }^{02}$ thus ruling out any attempt to harmonize Garmon II with Metropolitan Market on the basis of the organizational-recognitional picketing distmction. ${ }^{63}$

The major problem left unsettled by Chavez and Retail Clerks' Union is the procedure for ascertaining the existence, or lack of existence, of a majority in favor of the union in the absence of any statutory procedure for designation of employee representatives. ${ }^{64}$ The opinions suggest that membership in the union will not in itself be determinative; the employees must designate it as their representative. ${ }^{65}$ The designation must be freely inade without fear of reprisal. ${ }^{68}$ The majority sug-

Perhaps the strongest criticism urged against the "majority rule" notion by the dissent is that it is inconsistent with the remedy in other cases subject to the Jurisdictional Strike Act. Id. at 244, 339 P.2d at 846 (dissent). Section 1116 of the act authorizes rehef by injunction or damages against any jurisdictional strike without distinguishing between majority and minority unions (since there is no statutory certification procedure), and the cases construing it have never made any such distinction. See cases cited in note 32 supra, especially Voeltz v. Bakery Workers Union, 40 Cal.2d 382, 390, 254 P.2d 553, 558 (1953) (dissent), in which the dissent grounded its objection to the majority opinion on the theory that only one of the unions ought to be enjoined. The dissenting opinion in Retail Clerks' Union suggests that the effect of the majority opinion is to alter the extent of rehef available under the Jurisdictional Strike Act in true inter-union disputes, but the majority opinion is barren of any indication of such an intention. It would seem, therefore, that the result of the Chavez rule is that in disputes between unions both majority and minority unions may be enjoined, but where the dispute is between a union and unorganized employees a minority union may be enjoined but not a majority one, even though both situations are held to be covered by the Jurisdictional Strike Act-a rather anomalous result. It would seem that the majority would have been on sounder ground had it frankly relied on a reinterpretation of $\$ 923$ rather than bringing in the Jurisdictional Strike Act.

60 It would appear that this requirement of State law will apply also to cases governed by federal law, pursuant to $\$ 14$ (b) of the Labor Management Relations Act, 61 Stat. 151, 29 U.S.C. \& 164(b) (1958). See Algonsa Plywood \& Veneer Co. v. Wisconsin Employment Relations Bd., 336 U.S. 301 (1949), in which State law regulating, but not completely prohibiting, the union shop was held to govern cases subject to NLRB jurisdiction. The question will not arise in California unless the State law is construed as requiring something more than the federal law.

01 The injunction enjoined "any picketing ... for the purpose of forcing and inducing plaintiffs to nrake an agreement requiring plaintiffs' employees to becoune or remain meinbers of ... any ... labor organization, in order to obtain, retain or continue in employment ...." Retail Clerks' Union v. Superior Court, 52 A.C. 232, 237, 339 P.2d 839, 842 (1959). The injunction in Garmon, on the other hand, enjomed the unions "... from picketing the places of business of plaimtiffs . . . and from doing any other acts tending . . . to injure plaintiffs' business ...." Garmon v. San Diego Bldg. Trades Council, 49 Cal. 2d 595, 599, 320 P.2d 473, 475 (1958).

62 Chavez v. Sargent, 52 A.C. 174, 212, 339 P.2d 801, 825 (1959).

63 See note 48 supra and accompanying text. Any attempt to draw a line between organizational and recognitional picketing would have required consideration of difficult questions of fact in each case, since the distinction frequently becomes tenuous where picketing for alleged organizational purposes is pursued by appeals to customers or supphers, or where it is continued after failure of the union to gain recognition at an election.

64 Cal. Assembly Bill 419 (1959 Reg. Sess.) proposed such a statutory procedure for designation of employee representatives, along with other substantial changes in the law, but failed to be enacted.

65 Retail Clerks' Union v. Superior Court, 52 A.C. 232, 235, 339 P.2d 839, 841 (1959).

66 Chavez v. Sargent, 52 A.C. 174, 226 n.16, 339 P.2d 301, 834-35 n.16 (1959). 
gests that the employer and the union might cooperate in holding an election; indeed, it suggests that the employer who intends to sign a union or closed shop contract may find it necessary to do so in order to protect himself from the charge of committing the tort of forcing a union shop on an unwilling majority of his employees. ${ }^{67}$ The dissent agrees that this might be satisfactory where the parties agree, but sees no workable solution where the parties disagree as to the appropriate bargaming unit or refuse to cooperate. ${ }^{\text {es }}$

It does not appear, however, that this should prove to be an insoluble problem. The use of administrative procedures under the federal law may make the conduct of a labor election under the supervision of a court seem unusual, but surely it is not beyond the capability of a court of equity at a time when courts are managing property, operating railroads, and supervising school enrollments. The cases subject to the State law will necessarily involve relatively small, localized business operations. Where the employer is willing to sign the union or closed shop agreeinent but is unable to agree with the union in holding an election, an action for declaratory relief would seem appropriate; while where the employer is unwilling to sign, he should seek injunctive relief. Similar remedies should be available to the employees, while the union would be able to seek only declaratory rehief ${ }^{69}$ since acceptance of the proposed agreement is never mandatory to the employer. The judgment would take the form either of grant or denial of an injunction against the proposed agreement, or of a declaration that it would or would not be lawful to execute it.70

Three other features of Chavez suggest the possibility of additional related developments in the labor law of California. The first of these, implicit in the origin of Chavez, is the determination that Califorma shall have a uniform statewide labor law, precluding local regulation. The possibility of local regulation in other areas of labor relations is not completely closed, since the invalidation of the local ordinance appears to be based on conflict with State law, rather than complete occupation of the field by the State, ${ }^{71}$ but the court seems determined to develop a comprehensive labor law founded on Cahifornia Labor Code section $923 .{ }^{72}$

67 Ibid.

68 Retail Clerks' Union v. Superior Court, 52 A.C. 232, 247, 339 P.2d 839, 848 (1959) (dissent).

69 Declaratory relief would appear available to both the union and the employer under the principle that a "... party threatened with tort or penalty for an act committed or about to be committed, which he believes privileged, bas a legal interest in asserting and securing confirmation of his immunity from the threatened tort or penalty ...." BORCHARD, DECLARATORY JUDGMIENTs, 928 (2d ed. 1941). Declaratory relief is available where the issue turns on a disputed question of fact. R. G. Hamilton Corp. v. Corum, 218 Cal. 92, 21 P.2d 413 (1933). A suit for declaratory relief by either the union or the employer is essentially analogous to a suit by one accused of patent infringement for a declaration of noninfringement, held proper in E. Edelmann \& Co. v. Triple-A Specialty Co., 88 F.2d 852 (7th Cir. 1937), cert. denied, 300 U.S. 680 (1937), and approved sub silentio in Edward Katzinger Co. v. Clicago Metallic Mfg. Co., 329 U.S. 394 (1947). In each case a party accused of commission or preparation to commit a tort seeks a declaration that the act or proposed act is privileged.

70 Presumably there would be no basis for certification of a prevailing union as the representative of the einployees as is done by the NLRB under the federal law, since there is nothing in the California law which requires that the union be recognized as such. The effect of the California law is to protect the employer if he does recognize a majority union. With or without formal certification procedures, however, the practical result will probably be the same-the prevailing union will gain employer acceptance of the desired union or closed shop contract; the losing one will not.

71 Chavez v. Sargent, 52 A.C. 174, 188-89, 339 P.2d 801, 810 (1959). Note, however, the statenient that the declared legislative policy is "compreheusive of the field."

72 Possible lines of developinent are suggested by dicta in Chavez, discussed in text at note 75 infra, and Elsis v. Evans, 157 Cal. App. 2d 399, 321 P.2d 514 (1958), in wbich it was asserted 
A second feature of Chavez is the statement, twice repeated in the majority opmion and elaborated at length in the concurring opinion, that there may be an area in which the legislature may not vahilly interfere with the freedom of contract of employer and union. ${ }^{73}$ The majority opinion does not give any hint as to the circumstances in which such freedom of contract could be applicable, other than to say that it must be for lawful objectives and to rule out the Retail Clerks' Union situation as one of them. The concurring opimion is confined to urging that such a constitutionally protected area exists, relying on a number of early cases. ${ }^{74}$ It would seem unlikely that a majority of the court will adopt liberty of contract as a basis for labor law decisions in the near future.

Finally, Chavez suggests that Cahfornia Labor Code section 923 may be used by the court as a basis for the enforcement of democratic procedures and fairness within labor unions, on the theory that an employee in an unfairly run union has been deprived of his full freedom of self-organization and control..$^{75}$ Although the court does not indicate what form of rehef would be appropriate in the case of a union which had ceased to be representative of its membership, it states clearly that some type of rehef would be available.

\section{CONCLUSION}

In a field as controversial as labor relations, future developments are apt to be dependent on political fortunes and changes in the personnel of the courts. It would seem, however, that at least the holdings of Chavez and Retail Clerks' Union will stand. The recent decision in Stephenson v. City of Palm Springs, ${ }^{70}$ which relied squarely on the Chavez opinion and received the concurrence of one of the dissenters in Retail Clerks' Union and one of the justices appointed since the argument of that case, would tend so to indicate. Legislative change, though possible, has proven extremely difficult in the past. ${ }^{77}$

that dismissal of employees because of refusal to terminate their mernbership in a labor union was unlawful under $\S 923$.

73 Chavez v. Sargent, 52 A.C. 174, 185, 223, 227, 339 P.2d 801, 807, 833, 836 (1959).

74 The principal cases cited are Twin City Co. v. Harding Glass Co., 283 U.S. 353 (1931); Allgeyer v. Louisiana, 165 U.S. 578 (1897); New Method Laundry Co. v. MacCann, 174 Cal. 26, 161 Pac. 990 (1916) ; Ex parte Quarg, 149 Cal. 79, 84 Pac. 766 (1906); Ex parte Hayden, 147 Cal. 649, 82 Pac. 315 (1905); Ex parte Drexel, 147 Cal. 763, 82 Pac. 429 (1905); Ex parte Dickey, 144 Cal. 234, 77 Pac. 924 (1904); Snell v. Bradbury, 139 Cal. 379, 73 Pac. 150 (1903); Stimson Mill Co. v. Braun, 136 Cal. 122, 68 Pac. 481 (1902); Gibbs v. Tally, 133 Cal. 373, 65 Pac. 970 (1901); Credit Bureau v. Johnson, 61 Cal. App. 2d 834, 142 P.2d 963 (Super. Ct. 1943).

75 'No compact between an employer and a labor organization can deprive the employees initially or permanently of their 'freedom' to participate in the selection, or in the changing if they see fit, of their bargaining representatives. It ... would go beyond the issues at bench ... to consider at this time what limitations, if any, may reasonably be placed on such matters as the freedom of employees to reorganize, or to hold elections for the selection or retirement of their representatives, or to declare new objectives for collective bargaining negotiations. . . . And it is imperative to rernember that if the workmen bave no vote in choosing those who negotiate the terms and conditions under which they are to labor ... they have no voice at the bargaining table. This would not be the 'full freedom' which section 923 purports to insure thern; rather it would be sornething akin to serfdom." Chavez v. Sargent, 52 A.C. 174, 209, 339 P.2d 801,823 (1959).

7652 A.C. 421,340 P.2d 1009 (1959). The case involved a city ordinance prohibiting union and closed shops under circurnstances similar to those in Chavez, so that the issue of invalidating a union shop agreement was not directly involved. The decision was by a vote of $5-0$, with all the participating justices concurring in the opinion of the court, which relied directly on Chavez.

77 Only one major legislative change, the Jurisdictional Strike Act, CAL. LAB. CoDE $\$ \S 1115-$ 22 , has becoune effective since 1933 . The major unsuccessful attempts at legislative change 
Thus, the decisions of the Supreme Court of California in Garmon II, Chavez, and Retail Clerks' Union should mark the start of a new period of development in Califormia labor law. The court has taken California Labor Code section 923, which declares the welfare of the individual workman to be the objective of the law, as the basis of this development and announced its intention to use it to protect the individual workman and his employer from unions which are unrepresentative of their membership or of the employees affected by their action.

The court has specifically held that a demand for a union or closed shop agreement by a union which is not representative of a majority of the employees affected is unlawful. Picketing in support of such a demand has also been held unlawful. Conversely, sucl demands have been held lawful where made by a majority union. Less clear is the situation where a minority umion engages in organizational picketing, i.e., picketing unaccompanied by any immediate demand for recognition or conclusion of a union or closed shop agreement, but it would seem that this has been impliedly held unlawful as well. In reaching these results by construing the legislative intent embodied in some of the statutes concerned, notably the Jurisdictional Strike Act and California Labor Code section 921, the recent decisions, like those they modify, may seem not wholly satisfactory; no doubt this is the result of the strongly divergent opinions and pressures which exist in the field of labor relations.

The critical issue underlying the recent decisions, as well as the older ones, is the extent to which the statutory policy of fostering the growth of labor unions will be carried when it conflicts with the desires of the employees immediately affected. The line of cases based on $M c K a y$ justified umion action in such a situation on the basis of the competitive economic effect which unorganized shops in the industry were apt to have on the organized ones. ${ }^{78}$ In point of fact, the scope to be accorded to this union interest in conditions throughout an industry had been substantially eroded prior to Garmon, Chavez, and Retail Clerks' Union by the cases which found a superior public interest in the elimination of racial discrimination, the preservation of opportunity for the self-employed tradesman, the elimination of combinations in restramt of trade, and the like. ${ }^{79}$ The law now goes further and requires the union to obtain representative character on a majority basis before its interest in unorgamized employees may lawfully be given coercive effect. Chavez abandons the theory of overriding industry-wide union interest by subordinating the union interest to the freedom of choice of a majority of the employees affected.

include Assembly Bill 373 in 1939, which would have amended CAI. LAB. CODE $\$ 921$ specifically to authorize the umion and closed shop; the Hot Cargo and Secondary Boycott Act, CAI. LAB. CODE $\$ \S 1131-36$, adopted by Cal. Stats. 1941, ch. 623, §1, at 2079, approved at the general election of November 3, 1942, and held unconstitutional by In re Blaney, 30 Cal. 2d 643, 184 P.2d 892 (1947), which would have made hot cargo agreements and secondary boycotts unlawful; and Assembly Bill 419 in 1959, which would have modified the Jurisdictional Strike Act and established a system of administrative certification of collective bargaining representatives.

78 See, e.g., the statement in C.S. Smith Metropolitan Market Co. v. Lyons, 16 Cal. $2 \mathrm{~d} 389$, 401,106 P.2d 414, 421 (1940): "The members of a labor organization may have a substantial interest in the employment relations of an einployer although none of them is or ever has been employed by him. The ... employment relations of every employer affect the working conditions and bargaining power of employees throughout the industry in whicl he competes... . The market for a product may be so competitive that one producer cannot maintain higher labor standards ... than those maintained by his nonumion competitors. Nor is the interest of the union ... less substantial where the labor standards of the nonunion shop are on an equality with those of its umion competitors."

79 See notes 26-33 supra. 
In the period since legislative recognition and approval have been conferred on the organizing efforts of labor unions, the courts have been faced with two alternatives in ensuring that union power is exercised responsibly. The first is to withdraw judicial protection from union activities in circunstances where they are considered undesirable and to find them unlawful; this has been the whole trend of the unlawful purpose cases and is the approach taken in Garmon II, Chavez, and Retail Clerks' Union. The other alternative is to treat the labor union as an organization clothed with a public trust and subject to compreliensive regulation in the public interest such as exists for public utilities. $A$ few of the cases have looked in this direction, and the dissent urged these in opposition to the majority's approach. ${ }^{80}$ On balance it would seem that the law along the latter hine is far too undeveloped to justify reliance on it at this tine.

But whatever view one takes, one thing seems certain-coming as they do at a time when the area effectively governed by the State law may well have been substantially expanded, the new developments assume particular inportance and may be expected to be the subject of still further judicial concern.

James W. Dilworth

80 Retail Clerks' Union v. Superior Court, 52 A.C. 232, 246, 339 P.2d 839, 847 (1959) (dissent). The principle case cited is Thornan v. International Alliance of Theatrical Employees, 49 Cal. 2d 629, 320 P.2d 494 (1958), where an applicant who was otherwise qualified for membership in a union with a closed shop contract was admitted by court order even though he failed to receive a favorable vote of the membership. 